UDC 577.112:616

\title{
INHIBITION OF IRE1 MODIFIES HYPOXIC REGULATION OF G6PD, GPI, TKT, TALDO1, PGLS AND RPIA GENES EXPRESSION IN U87 GLIOMA CELLS
}

\author{
O. H. MINCHENKOㄹ, I. A. GARMASH ${ }^{1}$, D. O. MINCHENKO ${ }^{1,2}$, \\ A. Y. KUZNETSOVA ${ }^{1}$, O. O. RATUSHNA
}

${ }^{1}$ Palladin Institute of Biochemistry, National Academy of Sciences of Ukraine, Kyiv; e-mail: ominchenko@yahoo.com;

${ }^{2}$ Bohomolets National Medical University, Kyiv, Ukraine

\begin{abstract}
We have studied the effect of hypoxia on the expression level of mRNA of the basic enzymes of pentosephosphate cycle (G6PD, TKT, TALDO1, PGLS and RPIA) and glucose-6-phosphate isomerase (GPI) in U87 glioma cells in relation to inhibition of IRE1 (inositol requiring enzyme 1). It was shown that hypoxia leads to up-regulation of the expression of GPI and PGLS genes and to down-regulation of TALDOI and RPIA genes in control glioma cells. Changes for GPI gene were more significant than for other genes. At the same time, inhibition of IRE1 modified the effect of hypoxia on the expression of all studied genes. In particular, it increased sensitivity to hypoxia of G6PD and TKT genes expression and suppressed the effect of hypoxia on the expression of GPI and RPIA genes. Additionally, inhibition of IREI eliminated hypoxic regulation of $P G L S$ gene and did not change significantly effect of hypoxia on the expression of TALDO1 gene in glioma cells. Present study demonstrated that hypoxia, which often contributes to tumor growth, affects the expression of most studied genes and inhibition of IREI modified the hypoxic regulation of pentose-phosphate cycle gene expressions in a gene specific manner and thus possibly contributes to slower glioma growth, but several aspects of this regulation warrant further investigation.
\end{abstract}

Key words: mRNA expression, GPI, G6PD, TKT, TALDO1, PGLS, RPIA, IRE1 inhibition, hypoxia, U87 glioma cells.

$\mathrm{P}$ entose phosphate pathway of glucose metabolism plays an important role in the regulation of various processes both in normal and pathological conditions, especially in glioma growth, and depends on endoplasmic reticulum stress, which is obligate component of cancer growth [1-4]. Malignant gliomas are highly aggressive tumors and are characterized by marked angiogenesis and extensive tumor cell invasion into the normal brain parenchyma. It was previously shown that blockade of IRE1mediated signaling pathway of endoplasmic reticulum stress leads to suppression of cell proliferation and tumor growth through changing the expression level of genes, which are responsible for control of glycolysis, cell cycle, apoptosis, angiogenesis and many other processes [4-9]. Hypoxic condition is also an important factor of cancer growth and par- ticipates in the induction of endoplasmic reticulum stress [10, 11].

Recently, interest in the role of the pentose phosphate pathway in cancer has been renewed $[3,4]$. This metabolic pathway is advantageous for rapidly growing cells because it provides nucleotide precursors, which are needed for nucleic acids synthesis and intensification of cell proliferation, and helps regenerate the reducing agent NADPH, which can contribute to reactive oxygen species scavenging. Pentose phosphate pathway genes such as G6PD (glucose-6-phosphate dehydrogenase), TKT (transketolase), TALDO1 (transaldolase 1), PGLS (6-phosphoglucolactonase) та RPIA (ribose-5-phosphate isomerase) as well as GPI (glucose phosphate isomerase) gene play an important role in malignant tumor growth [2-4]. G6PD is the rate-limiting en-

\footnotetext{
(C) 2017 Minchenko O. H. et al. This is an open-access article distributed under the terms of the Creative Commons Attribution License, which permits unrestricted use, distribution, and reproduction in any medium, provided the original author and source are credited.
} 
zyme of the pentose phosphate pathway and is also involved in apoptosis as well as angiogenesis [4, 12, 13]. Moreover, G6PD may regulate apoptosis and expression of cell cycle-related proteins through phosphorylation of transcription factors STAT3 and STAT5, thus mediating formation and growth of malignant cells [14]. It is interesting to note that TAp73, a structural homologue of the pre-eminent tumor suppressor TP53, as well as SIRT2 enhances the pentose phosphate pathway and NADPH production and promotes cell proliferation through glucose-6-phosphate dehydrogenase $[15,16]$. Recent data indicates that the transcription factor NRF2 is responsible for regulating G6PD and TKT gene expressions, and oncogenes can realize its effect via stabilization or degradation of the transcription factor [17].

Transaldolase is a key enzyme of the nonoxidative pentose phosphate pathway providing ribose5-phosphate for nucleic acid synthesis and NADPH for lipid biosynthesis [18]. This enzyme as well as TKT are important for the balance of metabolites in the pentose-phosphate pathway and involved in mitochondrial homoeostasis, oxidative stress, apoptosis, multiple sclerosis, and cancer [2, 18-20]. PGLS та RPIA enzymes of pentose phosphate pathway also participated in malignant tumor growth [1, 21, 22]. Therefore, there is data that microRNA-124 reduces the pentose phosphate pathway, inhibits DNA synthesis and proliferation by targeting RPIA mRNA in human colorectal cancer cells and that RPIA regulates hepatocarcinogenesis via PP2A and ERK signaling [22, 23].

Phosphoglucose isomerase (PGI) is a multifunctional enzyme that functions in glucose metabolism as a glycolytic enzyme catalyzing an interconversion between glucose and fructose inside the cell, while it acts as cytokine outside the cell, with properties that include autocrine motility factor (AMF)-regulating tumor cell motility [24]. It was shown that AMF/PGI mediates epithelial and mesenchymal phenotype conversions in breast cancer and its overexpression induces epithelialto-mesenchymal transition with enhanced malignancy and that silencing of AMF/PGI resulted in mesenchymal-to-epithelial transition of human lung fibrosarcoma cells and breast cancer cells with reduced malignancy [24, 25]. It was also shown that overexpression of AMF/PGI significantly contributes to the aggressive phenotype of human cancer, but downregulation of its expression and subsequent abrogation of AMF/PGI secretion is resulted in mor- phologic change with reduced growth, motility, and invasion [25, 26]. PGI/AFM also regulates endoplasmic reticulum stress and cell death through control of endoplasmic reticulum calcium release as well as promotes cell survival by the pAKT survival pathway [27]. Its receptor, AMFR, is an E3 ubiquitin ligase implicated in endoplasmic reticulum-associated protein degradation. Furthermore, AMF/PGI also protects against tunicamycin-induced endoplasmic reticulum stress and apoptosis [27]. It is interesting to note that HER2 expression and AMF/PGI secretion were inversely related in breast carcinoma cells. Thus, AMF/PGI may contribute to HER2-mediated breast cancer progression [28].

The endoplasmic reticulum is a key organelle in the cellular response to hypoxia and some chemicals, which activate a complex set of signaling pathways named the unfolded protein response/endoplasmic reticulum stress, which controls numerous processes including proliferation $[6,29]$. The signaling enzyme IRE1 has two distinct catalytic domains: serine/threonine kinase and endoribonuclease. Both domains contributed to ERN1 signaling [30]. The IRE1-associated protein kinase autophosphorylates and dimerizes this enzyme in the endoplasmic reticulum membrane, leading to the activation of its endoribonuclease domain, and has some additional functions [7]. Endoribonuclease activity is responsible for degradation of a specific subset of mRNA and initiation of the pre-XBP1 (X-box binding protein 1) mRNA splicing that stimulates the expression of more than five hundreds of unfolded protein response-specific genes [6, 30,31]. It is possible that this activation of the ERN1 endoribonuclease is a result of its interaction with other sensor-signalling systems of endoplasmic reticulum stress.

Tumor growth is tightly associated with the endoplasmic reticulum stress response-signaling pathway and hypoxia, which are linked to the neovascularization and cell death processes [32-34]. Multiple studies have clarified the link between cancer and endoplasmic reticulum stress, which controls different processes including cell proliferation and surviving as well as circadian rhythms [32, 35]. Furthermore, the inhibition of IRE1 as a central mediator of the unfolded protein response leads to suppression of tumor growth through down-regulation of key pro-angiogenic and pro-proliferative factors and up-regulation of tumor suppressor genes as well as through modification of hypoxic regulation of these genes [4, 6]. However, the executive mechanisms of the exhibited anti-proliferative effects of 
IRE1 inhibition are not yet known. It is possible that this anti-proliferative effect is also mediated by altered expression of pentose phosphate pathway genes, which are integrated into the unfolded protein response signaling pathways and regulate cell proliferation [1, 2, 32, 34, 36].

The main goal of this study was to investigate the pentose phosphate pathway genes (G6PD, TKT, TALDO1, PGLS, and RPIA) as well as glycolytic enzyme gene (GPI) expression in glioma U87 cells upon hypoxia for evaluation of their possible significance for the control of glioma cell proliferation through IRE1 mediated signaling.

\section{Materials and Methods}

Cell Lines and Culture Conditions. The glioma cell line U87 (HTB-14) was obtained from ATCC (USA) and grown in high glucose (4.5 g/l) Dulbecco's modified Eagle's minimum essential medium (DMEM; Gibco, Invitrogen, USA) supplemented with glutamine (2 mM), 10\% fetal bovine serum (Equitech-Bio, Inc., USA), penicillin (100 units/ml; Gibco, USA) and streptomycin (0.1 mg/ml; Gibco) at $37^{\circ} \mathrm{C}$ in a $5 \% \mathrm{CO}_{2}$ incubator. To model hypoxia culture plates were incubated in special chamber with $3 \%$ oxygen, $92 \%$ nitrogen, and 5\% carbon dioxide for $16 \mathrm{~h}$.

In this study we used sublines of U87 glioma cells, which were described previously [5,9]. One subline was obtained by selection of stable transfected clones with overexpression of vector pcDNA3.1, which was used for creation of dnIRE1 (dominant/ negative IRE1). This untreated subline of glioma cells (control glioma cells) was used in the study of the effect of hypoxia on the expression level of G6PD, TKT, TALDOI, PGLS, RPIA, and GPI genes. The second subline was obtained by selection of stable transfected clone with overexpression of IRE1 dominant/negative construct (dnIRE1) and consequent inhibition of both protein kinase and endoribonuclease activities of this signaling enzyme of endoplasmic reticulum stress [6]. Effect of hypoxia on the expression levels of studied genes in these two sublines of glioma cells were compared with corresponding levels in cells, transfected by vector or by dnIRE1. The efficiency of IRE1 suppression in this glioma cell subline was estimated previously $[6,7]$ by determining the expression level of spliced XBP1, a key transcription factor in the IRE1 signaling, and the level of the phosphorylated IRE1 isoform in cells treated by tunicamycin $(0.01 \mathrm{mg} / \mathrm{ml}$ during $2 \mathrm{~h})$.
Both sublines of glioma cells used in this study were grown with addition of geneticin (G418), while these cells carry an empty pcDNA3.1 vector or dnIRE1 construct.

RNA isolation. Total RNA was extracted from glioma cells using Trizol reagent according to manufacturer protocol (Invitrogen, USA) as described previously $[7,9]$. The RNA pellets were washed with 75\% ethanol and dissolved in nuclease-free water. For additional purification, RNA samples were re-precipitated with 95\% ethanol and re-dissolved again in nuclease-free water. RNA concentration and spectral characteristics were measured using NanoDrop Spectrophotometer ND1000 (PEQLAB, Biotechnologie $\mathrm{GmbH}$ ).

Reverse transcription and quantitative PCR analysis. QuaniTect Reverse Transcription Kit (QIAGEN, Germany) was used for cDNA synthesis according to manufacturer protocol. The expression levels of GPI, G6PD, TKT, TALDO1, PGLS, and RPIA mRNAs as well as ACTB mRNA were measured in U87 glioma cells by real-time quantitative polymerase chain reaction using Mx 3000P QPCR (Stratagene, USA) or RotorGene RG-3000 qPCR (Corbett Research, Germany) and Absolute qPCR SYBRGreen Mix (Thermo Fisher Scientific, ABgene House, UK). Polymerase chain reaction was performed in triplicate using specific pair of primers, which were received from Sigma-Aldrich, USA.

For amplification of GPI (glucose-6-phosphate isomerase) cDNA we used forward (5'-CGCCCAACCAACTCTATTGT- $3^{\prime}$ and reverse (5'-GGTAGAAGCGTCGTGAGAGG- ${ }^{\prime}$ ) primers. The nucleotide sequences of these primers correspond to sequences 1554-1573 and 1766-1747 of human GPI cDNA (GenBank accession number NM_000175). The size of amplified fragment is $213 \mathrm{bp}$.

For amplification of G6PD (glucose-6-phosphate dehydrogenase) we used forward (5'-GAGGCCGTGTACACCAAGAT $-3^{\prime}$ and reverse (5'TACCCAAGGCCGTACTTGTC-3') primers. The nucleotide sequences of these primers correspond to sequences 1430-1439 and 1644-1625 of human G6PD cDNA (GenBank accession number NM_000402). The size of amplified fragment is 215 bp.

The amplification of TALDO1 (transaldolase 1) cDNA for real time RCR analysis was performed using two oligonucleotides primers: forward $-5^{\prime}-$ GGCTGTGACTTCCTCACCAT- ${ }^{\prime}$ ' and reverse $-5^{\prime}-$ CTCAGGGATGCGCTACTTTC- 3 '. The nucleotide sequences of these primers correspond to sequences 
795-814 and 1076-1057 of human TALDO1 cDNA (GenBank accession number NM_006755). The size of amplified fragment is $282 \mathrm{bp}$.

For amplification of TKT (transketolase) cDNA we used forward (5'-GACAACCTTGTGGCCATTCT $-3^{\prime}$ and reverse ( $5^{\prime}$-TCTGCTCAGCCATGTTTTTG-3') primers. The nucleotide sequences of these primers correspond to sequences 698-717 and 980-961 of human TKT cDNA (GenBank accession number NM_012088). The size of amplified fragment is $283 \mathrm{bp}$.

The amplification of PGLS (6-phosphogluconolactonase) cDNA for real time RCR analysis was performed using two oligonucleotides primers: forward - 5'-CTGCTCACTCTTCCCAGACC- $3^{\prime}$ and reverse (5'-TCCAGTTGCCACAAAGATGA-3'). The nucleotide sequences of these primers correspond to sequences 515-534 and 665-646 cDNA of human PGLS (GenBank accession number NM_012088). The size of amplified fragment is $151 \mathrm{bp}$.

For amplification of RPIA (5-phosphate isomerase A) cDNA we used forward (5'-AGTGCTGGGAATTGGAAGTG-3' and reverse (5'CGATCACGATGAAGCGACTA-3') primers. The nucleotide sequences of these primers correspond to sequences 335-354 and 627-608 of human RPIA cDNA (GenBank accession number NM_144563). The size of amplified fragment is $293 \mathrm{bp}$.

The amplification of beta-actin (ACTB) cDNA was performed using forward - 5'-GGACTTCGAGCAAGAGATGG-3' and reverse - 5'-AGCACTGTGTTGGCGTACAG-3' primers. These primer nucleotide sequences correspond to 747-766 and 980-961 of human ACTB cDNA (NM_001101). The size of amplified fragment is $234 \mathrm{bp}$. The expression of beta-actin mRNA was used as control of analyzed RNA quantity. The primers were received from Sigma-Aldrich (St. Louis, MO, USA).

Quantitative PCR analysis was performed using "Differential expression calculator" software. The values of G6PD, TKT, TALDO1, PGLS, RPIA and GPI gene expressions were normalized to the expression of beta-actin mRNA and represented as percent of control (100\%). All values are expressed as mean \pm SEM from triplicate measurements performed in 4 independent experiments. The amplified DNA fragments were also analyzed on a $2 \%$ agarose gel and visualized by SYBR* Safe DNA Gel Stain (Life Technologies, Carlsbad, CA, USA).

Statistical analysis. Statistical analysis was performed according to Student's t-test using Excel program as described previously [37]. All values are expressed as mean \pm SEM from triplicate measurements performed in 4 independent experiments.

\section{Results and Discussion}

To determine if hypoxia affects the expression of a subset of genes encoding pentose phosphate pathway enzymes, such as G6PD (glucose-6-phosphate dehydrogenase), TKT (transketolase), TALDO1 (transaldolase 1), PGLS (6-phosphoglucolactonase), and RPIA (ribose-5-phosphate isomerase), as well as GPI (glucose phosphate isomerase) through the IRE1 branch of endoplasmic reticulum stress response, we investigated the effect of hypoxia on the expression level of these genes in control glioma cells (transfected by vector) and cells without both enzymatic activities of this signaling enzyme.

As shown in Fig. 1, hypoxia strongly up-regulated the expression level of GPI mRNA $(+124 \%)$ in control glioma cells as compared to control 1 . To investigate a possible role of endoplasmic reticulum stress signaling mediated by IRE1 enzyme in regulation of the expression of GPI gene by hypoxia, we investigated the effect of hypoxic condition on this gene expression in glioma cells without enzymatic activities of this signaling enzyme. It was shown that inhibition of the signaling enzyme IRE1 by dnIRE1 significantly modifies the effect of hypoxia on the expression level of GPI gene as compared to control glioma cells (Fig. 1). Thus, the effect of hypoxia on the expression level of GPI gene in glioma cells with knockdown of IRE1 signaling enzyme is significantly lesser (+58\% versus control 2) in comparison to control glioma cells.

As shown in Fig. 2, hypoxia does not change significantly the expression level of G6PD mRNA in control glioma cells (as compared to control 1); however, inhibition of IRE1 signaling enzyme leads to significant down-regulation of this gene expression (-55\% as compared to control 2). Therefore, inhibition of IRE1 introduces the hypoxic regulation of $G 6 P D$ gene expression in glioma cells.

Investigation of the expression of transaldolase 1 gene in control U87 glioma cells and cells with IRE1 knockdown has shown that hypoxia significantly decreases the expression levels of TALDO1 mRNA in control U87 glioma cells (-31\% as compared to control 1) and that inhibition of the signaling enzyme IRE1 by dnIRE1 does not significantly modify this effect of hypoxia ( $-40 \%$ as compared to control 2; Fig. 3). 


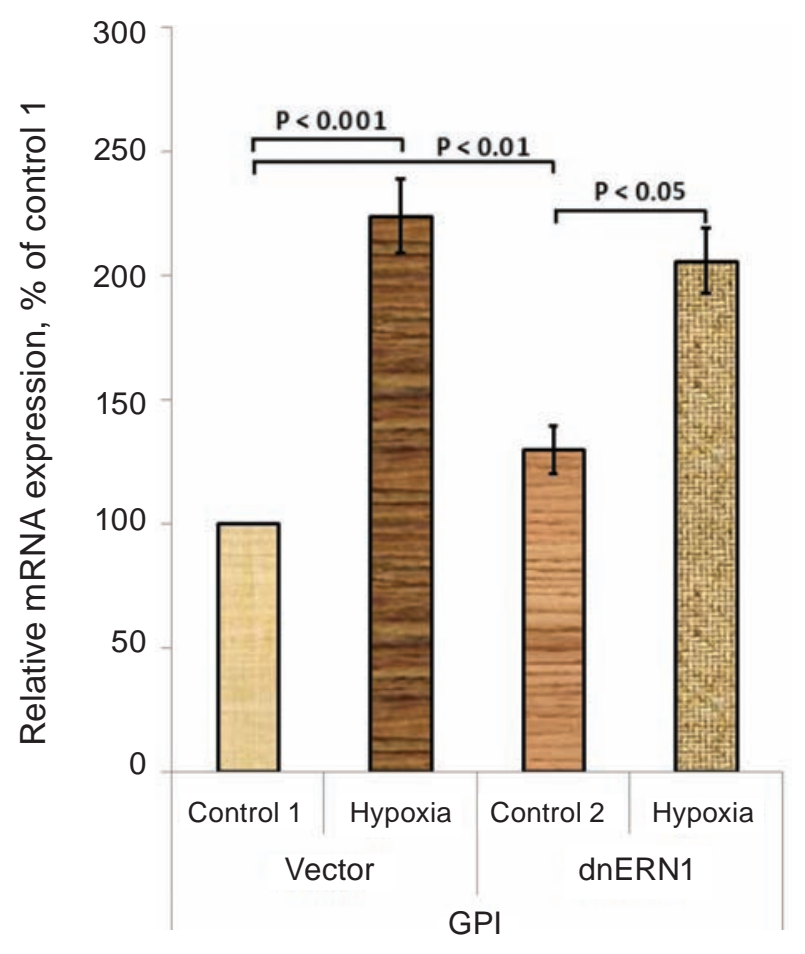

Fig. 1. Effect of hypoxia (3\% oxygen - 16 h) on the expression level of GPI (glucose phosphate isomerase) gene in control U87 glioma cells (Vector) and cells with IRE1 knockdown (dnIREI) measured by $q P C R$. The values of GPI mRNA expression were normalized to $\beta$-actin $m R N A$ level and presented as percent of control (100\%); $n=4$

As shown in Fig. 4, hypoxia meaningfully down-regulates the expression level of ribose5-phosphate isomerase mRNA in control glioma cells (-39\% as compared to control 1) and inhibition of IRE1 signaling enzyme also leads to induction of this gene expression but this effect of hypoxia is slightly smaller (-27\% as compared to control 2$)$. Therefore, inhibition of IRE1 slightly decreases the hypoxic regulation of RPIA gene expression in U87 glioma cells.

We also investigated the expression of $P G L S$ gene upon hypoxia in both control glioma cells and cells without IRE1 signaling enzyme function. As shown in Fig. 5, hypoxia causes small but statistically significant up-regulation of gene expression in control glioma cells ( $+13 \%$ as compared to control 1$)$. IRE1 inhibition almost completely eliminates the effect of hypoxia on this gene expression as compared to control 2 (Fig. 5).

Results of investigation of TKT gene expression is presented in Fig. 6. In control glioma cells the expression level of this gene is resistant to hypoxic treatment (3\% oxygen for $16 \mathrm{hrs})$. At the same time, inhibition of IRE1 by dnIRE1 leads to significant down-regulation of the expression level of transketolase mRNA in U87 glioma cells (-48\% as compared to control 2; Fig. 6).

Therefore, the effect of hypoxia on the expression level of a subset of genes encoding different enzymes of pentose phosphate pathway as well as GPI gene depended on IRE1 signaling enzyme function, because inhibition of IRE1 significantly modifies hypoxic regulation of these genes expression: eliminates effect of hypoxia on the expression of $P G L S$ gene (Fig. 5) and introduces sensitivity to hypoxia of G6PD and TKT genes (Fig. 6). Moreover, as shown in Fig. 7, the effect of hypoxia on the expression level of GPI and RPIA genes is significantly suppressed and enhanced on TALDOI gene in glioma cells by inhibition of IRE1 signaling enzyme function.

In this work we studied the effect of hypoxia on the expression of a subset of genes encoding diffe-

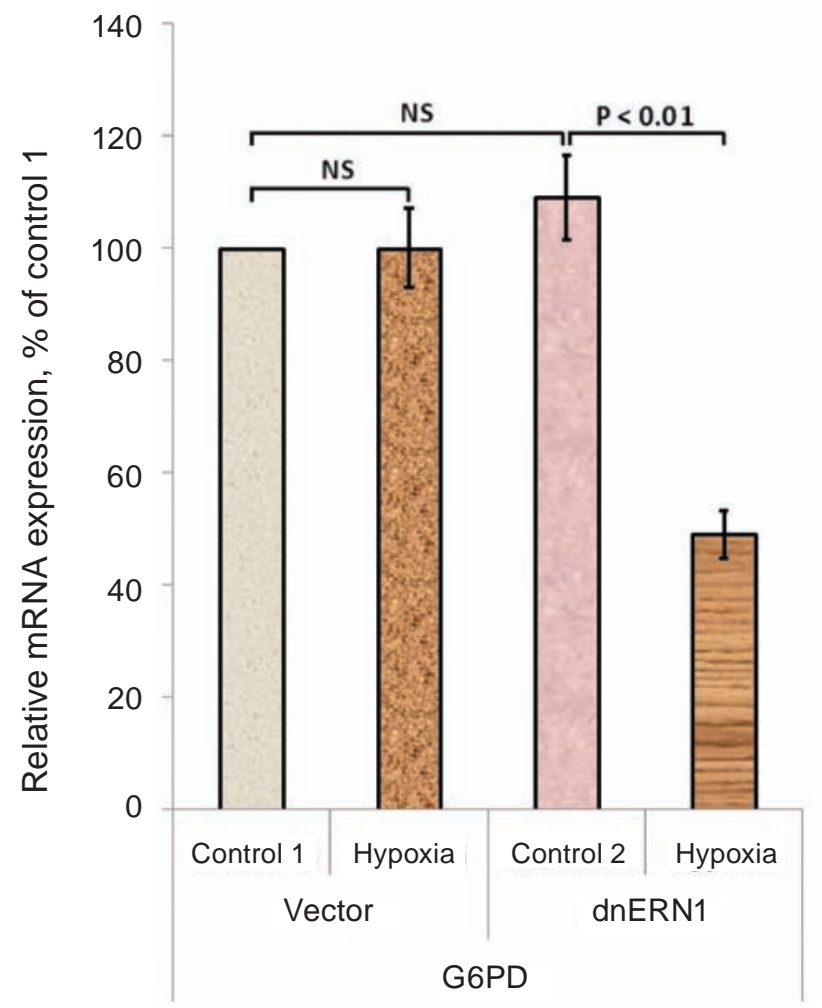

Fig. 2. Effect of hypoxia on the expression level of G6PD (glucose-6-phosphate dehydrogenase) gene in control U87 glioma cells (Vector) and cells with IRE1 knockdown (dnIRE1) measured by qPCR. The values of G6PD mRNA expression were normalized to $\beta$-actin $m R N A$ level and presented as percent of control (100\%); $n=4$ 


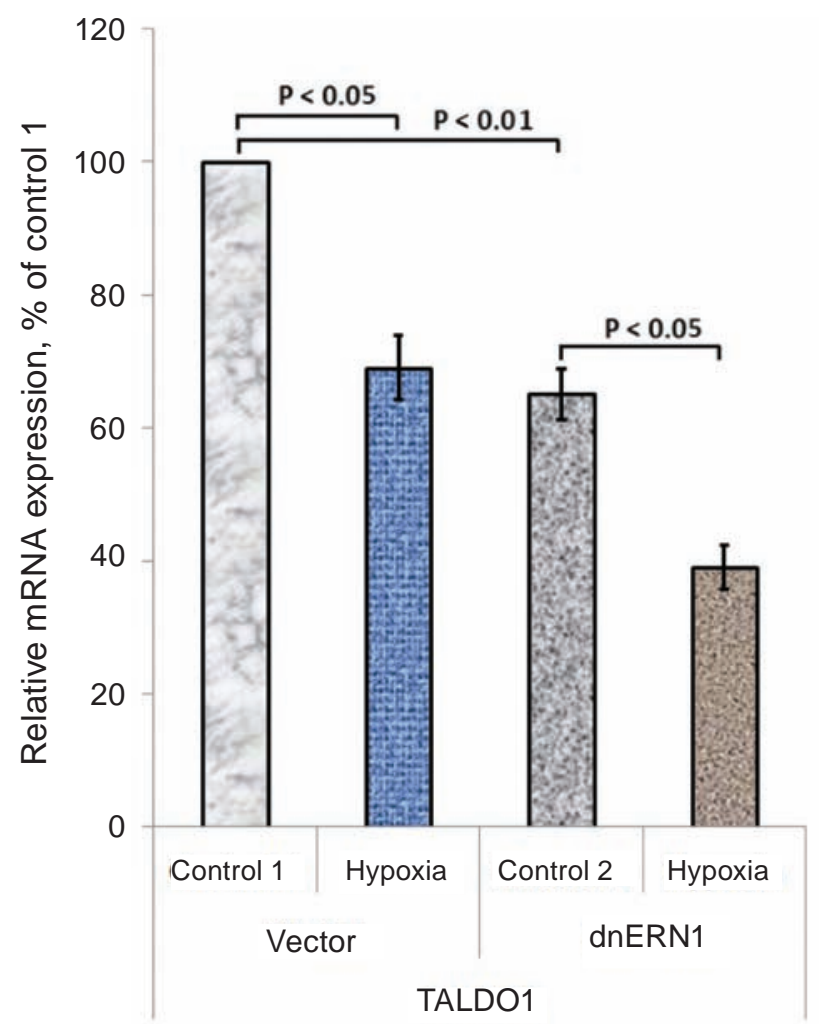

Fig. 3. Effect of hypoxia on the expression level of TALDO1 (transaldolase 1) gene in control U87 glioma cells (Vector) and cells with IRE1 knockdown (dnIRE1) measured by qPCR. The values of TALDO1 mRNA expression were normalized to $\beta$-actin $m R N A$ level and presented as percent of control $(100 \%) ; n=4$

rent enzymes of pentose phosphate pathway as well as one glycolytic enzyme (GPI) in U87 glioma cells with functionally active signaling enzyme IRE1 and cells with IRE1 knockdown for evaluation of possible significance of these genes in the control of glioma growth through endoplasmic reticulum stress signaling mediated by IRE1 and hypoxia. Investigation of the expression of G6PD, TKT, TALDO1, $P G L S, R P I A$, and GPI genes in glioma cells upon hypoxia in respect to inhibition of IRE1 signaling is important for understanding the malignant tumor growth mechanisms, because hypoxia as well as endoplasmic reticulum stress play an essential role in the control of tumor progression [10, 32, 34, 38, 39]. The growing tumor requires the endoplasmic reticulum stress and hypoxia for apoptosis inhibition, neovascularization and growth [5, 38, 40]. Cell proliferation is strongly dependent on hypoxia and glycolysis because there is the molecular connection between cell cycle progression and the provision of substrates essential for this purpose [6, 39, 40].

In this study we demonstrated that the expression of most studied genes in control glioma cells is affected by hypoxia as compared to cells growing upon normoxic condition. The expression level of GPI gene is increased in control glioma cells affected by hypoxia, but inhibition of IRE1 and consequent cell proliferation decreases this effect of hypoxia. It is well known that GPI/AMF has pro-proliferative properties because it contributes to energy pathways and as cytokine (not enzymatic activity) and its silencing resulted in mesenchymal-to-epithelial transition of human cancer cells with reduced malignancy [24-26]. Thus, our results are mostly consistent with numerous data $[9,10,27,40]$ that hypoxia associated with malignant progression through the endoplasmic reticulum unfolded protein response, but mechanisms through which malignant cells cope with potentially lethal metabolic stress induced by hypoxia remains poorly understood.

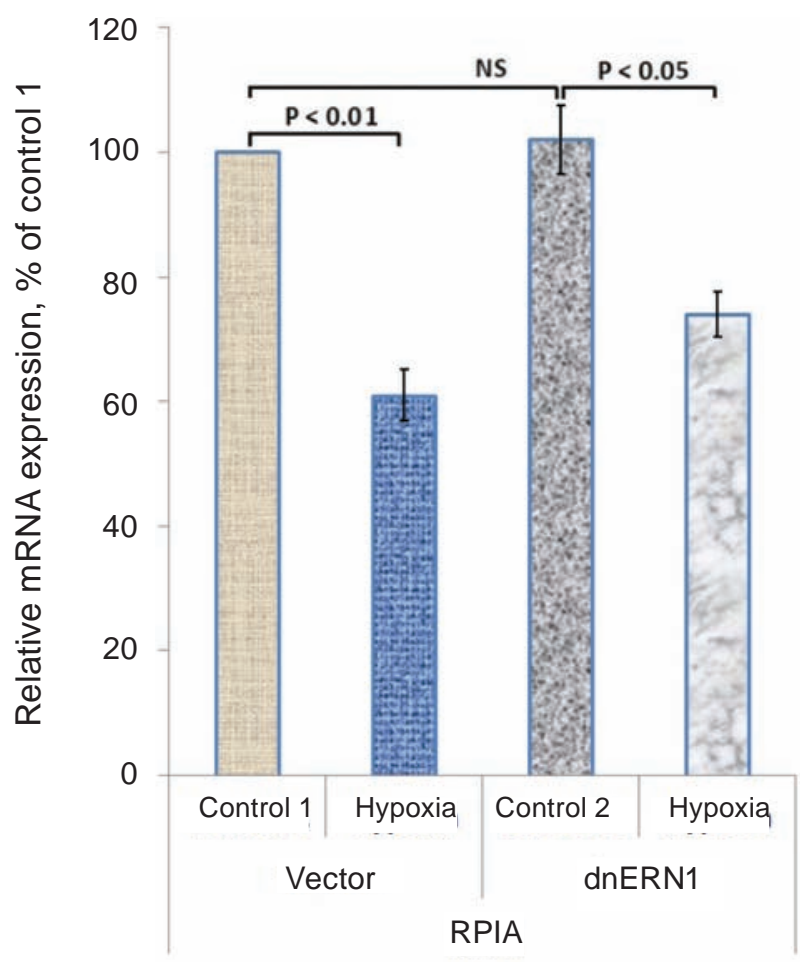

Fig. 4. Effect of hypoxia on the expression level of RPIA (ribose-5-phosphate isomerase) gene in control U87 glioma cells (Vector) and cells with IRE1 knockdown (dnIREl) measured by qPCR. The values of RPIA mRNA expression were normalized to $\beta$-actin $m R N A$ level and presented as percent of control (100\%); $n=4$ 


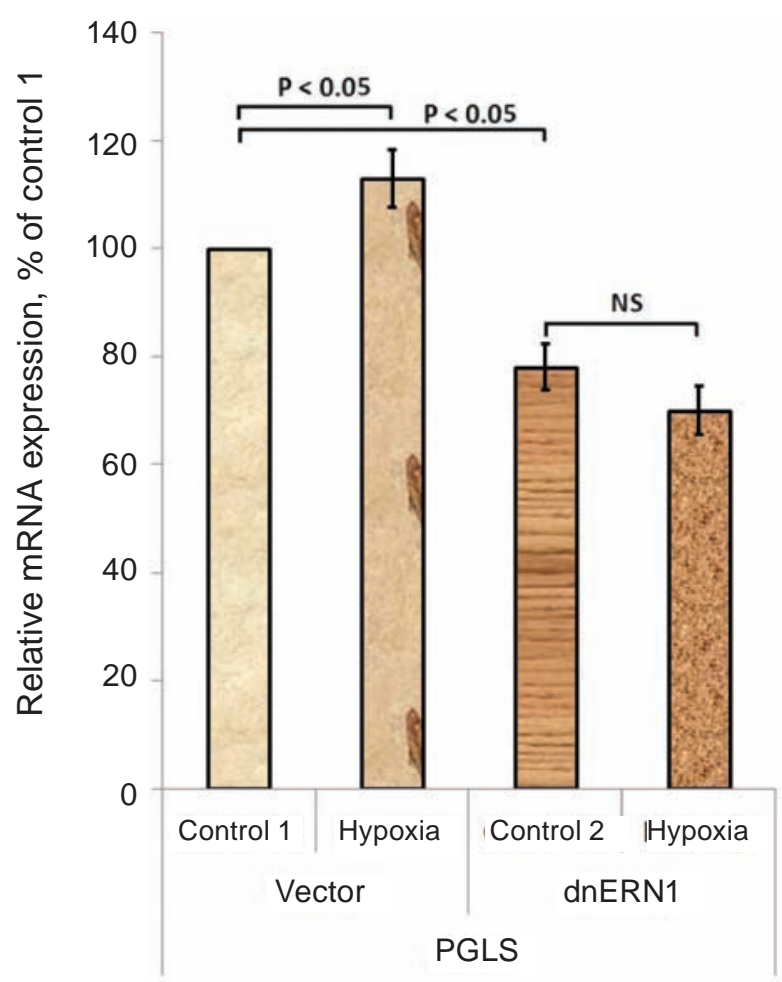

Fig. 5. Effect of hypoxia on the expression level of PGLS (6-phosphoglucolactonase) gene in control U87 glioma cells (Vector) and cells with IRE1 knockdown (dnIRE1) measured by qPCR. The values of $P G L S$ mRNA expression were normalized to $\beta$-actin $m R N A$ level and presented as percent of control $(100 \%) ; n=4$

At the same time, the expression of two other genes (G6PD and TKT) in control glioma cells is resistant to hypoxic treatment, but the expression level of TALDO1 and RPIA genes is decreased.

In case of G6PD and TKT genes, inhibition of IRE1 signaling enzyme introduces the hypoxic down-regulation of the expression of these genes. In contrast, IRE1 knockdown in U87 glioma cells decreased the sensitivity of RPIA gene expression to hypoxia. Only in case of TALDOI gene IRE1 inhibition resulted in increased sensitivity of this gene's expression to hypoxia in U87 glioma cells.

It is interesting to note, that treatment with hypoxia has different effect on the expression of studied genes in gene specific manner. Moreover, inhibition of IRE1 signaling enzyme modifies the hypoxic regulation of the expression of all studied genes also in gene specific manner. It is possible that molecular mechanisms of hypoxic regulation of different genes are complex and depend on not only the level of HIF-1 $\alpha$ protein. Recently, it was shown that hy-

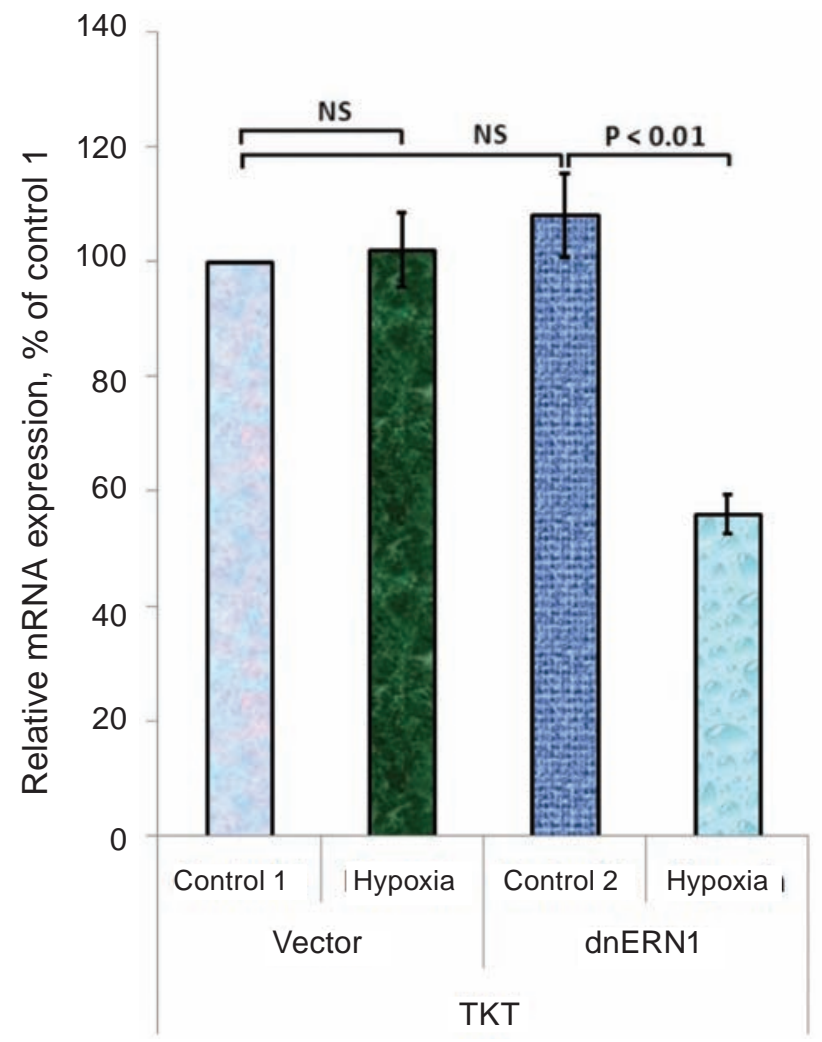

Fig. 6. Effect of hypoxia on the expression level of TKT (transketolase) gene in control U87 glioma cells (Vector) and cells with IRE1 knockdown (dnIRE1) measured by qPCR. The values of TKT $m R N A$ expression were normalized to $\beta$-actin $m R N A$ level and presented as percent of control (100\%); $n=4$

poxia significantly up-regulates HIF-1 $\alpha$ protein level both in control and IRE1 knockdown glioma cells but inhibition of IRE1 slightly reduces the level of this protein [41]. Our results support the idea that hypoxic regulation of different gene expressions is upon complex network, which is partially controlled by IRE1 signaling. It is known that suppression of IRE1 enzymatic activities in gliomas leads to the inhibition of tumor neovascularization together with the development of a more invasive phenotype [6]. It is reasonable to suggest, that combined impact of hypoxia and IRE1 inhibition on the expression of key regulatory factors may contribute to the decreased proliferation potential of IRE1 knockdown glioma cells. Similar results were obtained previously for hypoxic regulation of TP53, ZMAT3, IGFBP6, IGFBP7, NOV, WISP2, ATF3, TBX3, FOXF1, HOXC6 and some other genes [8, 10, 37, 41-45].

Therefore, the present study demonstrates that hypoxia, which usually contributes to tumor growth, affects almost all studied gene expressions and that 


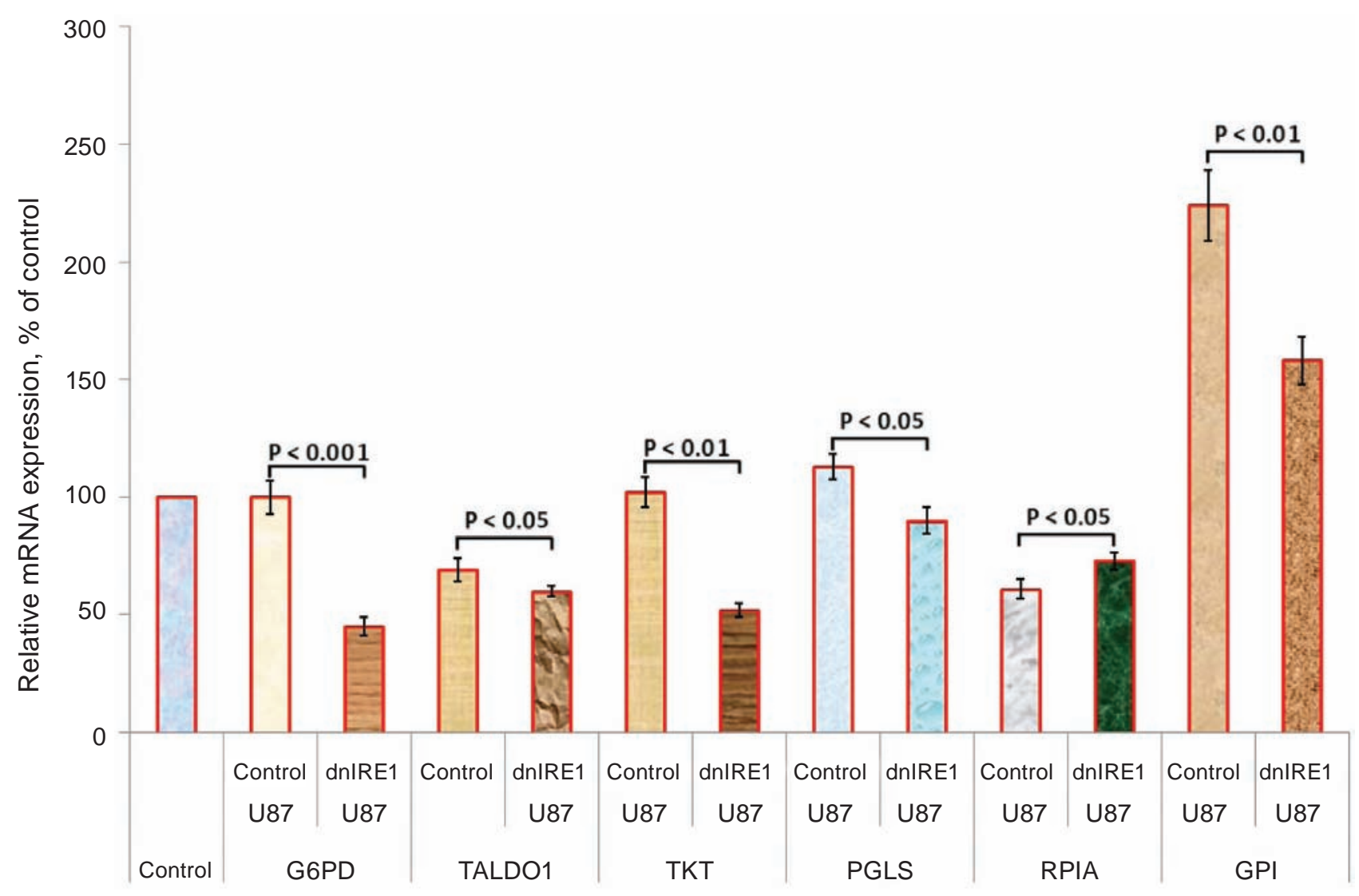

Fig. 7. Effect of hypoxia on the expression level of G6PD, TALDO1, TKT, PGLS, RPIA, and GPI mRNA in control U87 glioma cells stable transfected with empty vector (Control U87) and in cells without function of signaling enzyme IRE1 (dnIRE1 U87) measured by qPCR. Values of these mRNA expressions were normalized to $\beta$-actin $m R N A$ expression and represented as percent of corresponding control (100\%) versus no treated by hypoxia glioma cells; mean \pm SEM; $n=4$

inhibition of IRE1 can both enhance and suppress the hypoxic regulation of these gene expressions in gene specific manner and thus possibly contributes to slower glioma growth. However, the detailed mo- lecular mechanisms of IRE1-mediated hypoxic regulation of these genes, which have a pivotal role in the control of cell proliferation, are complex and warrant further investigation. 


\section{ПРИГНIЧЕННЯ IRE1 ЗМIНЮЄ ГІПОКСИЧНУ РЕГУЛЯЦІЮ ЕКСПРЕСIÏ ГЕНIВ G6PD, GPI, TKT, TALDO1, PGLS TA RPIA У КЛІТИНАХ ГЛІОМИ ЛІНІЇ U87}

\author{
О. Г. Мінченко , Я. А. Гармаш \\ Д. О. Мінченко ${ }^{1,2}$, А. Ю. Кузнєцова \\ О. О. Ратушна
}

$$
\begin{gathered}
{ }^{1} \text { Інститут біохімії ім. О. В. Палладіна } \\
\text { НАН України, Київ; } \\
\text { e-mail: оminchenko@уаһоо.com; } \\
{ }^{2} \text { Національний медичний університет } \\
\text { iм. О. О. Богомольця, Київ, Україна }
\end{gathered}
$$

Нами вивчено ефект гіпоксії на рівень експресії мРНК основних ензимів пентозо-фосфатного циклу метаболізму глюкози (G6PD, TKT, TALDO1, PGLS та RPIA), а також глюкозо6-фосфатізомерази (GPI) в клітинах гліоми лінії U87 в умовах пригнічення IRE1 (залежного від інозитолу ензиму 1). Встановлено, що гіпоксія призводила до посилення експресії генів GPI та $P G L S$ і зниження експресії генів TALDO1 та RPIA в контрольних клітинах гліоми, причому вираженіші зміни виявлено для гена GPI. У той самий час пригнічення IRE1 модифікувало ефект гіпоксії на експресію всіх досліджених генів. Зокрема, збільшувало чутливість до гіпоксії експресію генів G6PD та TKT і знижувало ефект гіпоксії на експресію генів GPI та RPIA. Разом із тим, пригнічення IRE1 знімало ефект гіпоксії на експресію гена $P G L S$, але істотно не змінювало цей ефект на рівень експресії гена TALDO1 в клітинах гліоми. Результати роботи продемонстрували, що гіпоксія, яка $€$ необхідним фактором росту пухлин, змінювала рівень експресії більшості досліджених генів, i що пригнічення IRE1 модифікувало гіпоксичну регуляцію експресії генів пентозо-фосфатного циклу геноспецифічно i, таким чином, можливо впливало на зниження росту гліоми, але деякі аспекти цієї регуляції потребують подальшого вивчення.

К л ю ч о в і с ло в а: експресія мРНК, GPI, G6PD, TKT, TALDO1, PGLS, RPIA, пригнічення IRE1, гіпоксія, клітини гліоми.

\section{УГНЕТЕНИЕ IRE1 ИЗМЕНЯЕТ \\ ГИПОКСИЧЕСКУЮ РЕГУЛЯЦИЮ \\ ЭКСПРЕССИИ ГЕНОВ G6PD, GPI, TKT, TALDO1, PGLS И RPIA В КЛЕТКАХ ГЛИОМЫ ЛИНИИ U87}

О. Г. Минченко ${ }^{1}$ Я. А. Гармам 1 ,

Д. О. Минченко ${ }^{1,2}$, А. Ю. Кузнечова 1 , О. О. Ратушна ${ }^{1}$

\author{
${ }^{1}$ Институт биохимии им. А. В. Палладина \\ НАН Украины, Киев; \\ e-mail: ominchenko@yahoo.com; \\ ${ }^{2}$ Национальный медицинский университет \\ им. А. А. Богомольца, Киев, Украина
}

Нами изучен эффект гипоксии на уровень экспрессии мРНК основных энзимов пентозофосфатного цикла метаболизма глюкозы (G6PD, TKT, TALDO1, PGLS и RPIA), а также глюкозо6-фосфатизомеразы (GPI) в клетках глиомы линии U87 при угнетении IRE1 (зависимого от инозитола энзима 1). Установлено, что гипоксия повышала экспрессию генов GPI и $P G L S$ и снижала экспрессию генов TALDO1 и RPIA в контрольных клетках глиомы, причем более выраженные изменения были выявлены для гена GPI. В то же время, угнетение IRE1 модифицировало эффект гипоксии на экспрессию всех исследованных генов, а именно увеличивало чувствительность к гипоксии экспрессию генов G6PD и TKТ и снижало эффект гипоксии на экспрессию генов GPI и RPIA. Вместе с тем, угнетение IRE1 снимало эффект гипоксии на экспрессию гена $P G L S$, но существенно не изменяло этот эффект на уровень экспрессии гена TALDO1 в клетках глиомы. Результаты этой работы продемонстрировали, что гипоксия, являющаяся необходимым фактором роста опухолей, изменяла уровень экспрессии большинства исследованных генов, и что угнетение IRE1 модифицировало гипоксическую регуляцию экспрессии генов пентозо-фосфатного цикла геноспецифически и, таким образом, возможно влияла на снижение роста глиомы, но некоторые аспекты этой регуляции нуждаются в дальнейшем изучении.

К л ю че вы е сл о ва: экспрессия мРНК, GPI, G6PD, TKT, TALDOI, PGLS, RPIA, угнетение IRE1, гипоксия, клетки глиомы. 


\section{References}

1. Wamelink MM, Struys EA, Jakobs C. The biochemistry, metabolism and inherited defects of the pentose phosphate pathway: a review. J Inherit Metab Dis. 2008; 31(6): 703-717.

2. Berry GT. The unexplored potential of the pentose phosphate pathway in health and disease. $J$ Inherit Metab Dis. 2008; 31(6): 661.

3. Du W, Jiang P, Mancuso A, Stonestrom A, Brewer MD, Minn AJ, Mak TW, Wu M, Yang X. TAp73 enhances the pentose phosphate pathway and supports cell proliferation. Nat Cell Biol. 2013; 15(8): 991-1000.

4. Rao X, Duan X, Mao W, Li X, Li Z, Li Q, Zheng $\mathrm{Z}, \mathrm{Xu} \mathrm{H}$, Chen $\mathrm{M}$, Wang PG, Wang $\mathrm{Y}$, Shen $\mathrm{B}$, Yi W. O-GlcNAcylation of G6PD promotes the pentose phosphate pathway and tumor growth. Nat Commun. 2015; 6: 8468.

5. Drogat B, Auguste P, Nguyen DT, Bouchecareilh M, Pineau R, Nalbantoglu J, Kaufman RJ, Chevet E, Bikfalvi A, Moenner M. IRE1 signaling is essential for ischemiainduced vascular endothelial growth factor-A expression and contributes to angiogenesis and tumor growth in vivo. Cancer Res. 2007; 67(14): 6700-6707.

6. Auf G, Jabouille A, Guérit S, Pineau R, Delugin $M$, Bouchecareilh $M$, Magnin $N$, Favereaux A, Maitre M, Gaiser T, von Deimling A, Czabanka M, Vajkoczy P, Chevet E, Bikfalvi A, Moenner M. Inositolrequiring enzyme 1alpha is a key regulator of angiogenesis and invasion in malignant glioma. Proc Natl Acad Sci USA. 2010; 107(35): 1555315558.

7. Auf G, Jabouille A, Delugin M, Guérit $S$, Pineau R, North S, Platonova N, Maitre M, Favereaux A, Vajkoczy P, Seno M, Bikfalvi A, Minchenko D, Minchenko O, Moenner M. High epiregulin expression in human U87 glioma cells relies on IRE1 $\alpha$ and promotes autocrine growth through EGF receptor. BMC Cancer. 2013; 13: 597.

8. Pluquet O, Dejeans N, Chevet E. Watching the clock: endoplasmic reticulum-mediated control of circadian rhythms in cancer. Ann Med. 2014; 46(4): 233-243.

9. Minchenko OH, Tsymbal DO, Minchenko DO, Moenner M, Kovalevska OV, Lypova NM. Inhibition of kinase and endoribonuclease activity of ERN1/IRE1 $\alpha$ affects expression of proliferationrelated genes in U87 glioma cells. Endoplasm Reticul Stress Dis. 2015; 2(1): 18-29.

10. Minchenko DO, Danilovskyi SV, Kryvdiuk IV, Bakalets TV, Lypova NM, Karbovskyi LL, Minchenko OH. Inhibition of ERN1 modifies the hypoxic regulation of the expression of TP53related genes in U87 glioma cells. Endoplasm Reticul Stress Dis. 2014; 1(1): 18-26.

11. Minchenko OH, Tsymbal DO, Minchenko DO, Kovalevska OV, Karbovskyi LL, Bikfalvi A. Inhibition of ERN1 signaling enzyme affects hypoxic regulation of the expression of E2F8, EPAS1, HOXC6, ATF3, TBX3 and FOXF1 genes in U87 glioma cells. Ukr Biochem J. 2015; 87(2): 76-87.

12. StantonRC.Glucose-6-phosphate dehydrogenase, NADPH, and cell survival. IUBMB Life. 2012; 64(5): 362-369.

13. Gregory MA, D'Alessandro A, AlvarezCalderon F, Kim J, Nemkov T, Adane B, Rozhok AI, Kumar A, Kumar V, Pollyea DA, Wempe MF, Jordan CT, Serkova NJ, Tan AC, Hansen KC, DeGregori J. ATM/G6PD-driven redox metabolism promotes FLT3 inhibitor resistance in acute myeloid leukemia. Proc Natl Acad Sci USA. 2016; 113(43): E6669-E6678.

14. Hu T, Zhang C, Tang Q, Su Y, Li B, Chen L, Zhang Z, Cai T, Zhu Y. Variant G6PD levels promote tumor cell proliferation or apoptosis via the STAT3/5 pathway in the human melanoma xenograft mouse model. BMC Cancer. 2013; 13: 251.

15. Jiang P, Du W, Yang X. A critical role of glucose6-phosphate dehydrogenase in TAp73-mediated cell proliferation. Cell Cycle. 2013; 12(24): 37203726.

16. Xu SN, Wang TS, Li X, Wang YP. SIRT2 activates G6PD to enhance NADPH production and promote leukaemia cell proliferation. Sci Rep. 2016; 6: 32734.

17. Shelton P, Jaiswal AK. The transcription factor NF-E2-related factor 2 (Nrf2): a protooncogene? FASEB J. 2013; 27(2): 414-423.

18. Samland AK, Sprenger GA. Transaldolase: from biochemistry to human disease. Int $J$ Biochem Cell Biol. 2009; 41(7): 1482-1494.

19. Xu IM, Lai RK, Lin SH, Tse AP, Chiu DK, Koh HY, Law CT, Wong CM, Cai Z, Wong CC, Ng IO. Transketolase counteracts oxidative stress to drive cancer development. Proc Natl Acad Sci USA. 2016; 113(6): E725-E734. 
20. Moriyama T, Tanaka S, Nakayama Y, Fukumoto M, Tsujimura K, Yamada K, Bamba T, Yoneda Y, Fukusaki E, Oka M. Two isoforms of TALDO1 generated by alternative translational initiation show differential nucleocytoplasmic distribution to regulate the global metabolic network. Sci Rep. 2016; 6: 34648.

21. Ou K, Yu K, Kesuma D, Hooi M, Huang N, Chen W, Lee SY, Goh XP, Tan LK, Liu J, Soon SY, Bin Abdul Rashid S, Putti TC, Jikuya H, Ichikawa T, Nishimura O, Salto-Tellez M, Tan P. Novel breast cancer biomarkers identified by integrative proteomic and gene expression mapping. J Proteome Res. 2008; 7(4): 1518-1528.

22. Qiu Z, Guo W, Wang Q, Chen Z, Huang S, Zhao F, Yao M, Zhao Y, He X. MicroRNA-124 reduces the pentose phosphate pathway and proliferation by targeting PRPS1 and RPIA mRNAs in human colorectal cancer cells. Gastroenterology. 2015; 149(6): 1587-1598.

23. Ciou SC, Chou YT, Liu YL, Nieh YC, Lu JW, Huang SF, Chou YT, Cheng LH, Lo JF, Chen MJ, Yang MC, Yuh CH, Wang HD. Ribose-5-phosphate isomerase $\mathrm{A}$ regulates hepatocarcinogenesis via PP2A and ERK signaling. Int J Cancer. 2015; 137(1): 104-115.

24. Li Y, Jia Y, Che Q, Zhou Q, Wang K, Wan XP. AMF/PGI-mediated tumorigenesis through MAPK-ERK signaling in endometrial carcinoma. Oncotarget. 2015; 6(28): 2637326387.

25. Niinaka Y, Harada K, Fujimuro M, Oda M, Haga A, Hosoki M, Uzawa N, Arai N, Yamaguchi S, Yamashiro M, Raz A. Silencing of autocrine motility factor induces mesenchymalto-epithelial transition and suppression of osteosarcoma pulmonary metastasis. Cancer Res. 2010; 70(22): 9483-9493.

26. Lincet H, Icard P. How do glycolytic enzymes favour cancer cell proliferation by nonmetabolic functions? Oncogene. 2015; 34(29): 3751-3759.

27. $\mathrm{Fu} \mathrm{M}, \mathrm{Li} \mathrm{L}$, Albrecht T, Johnson JD, Kojic LD, Nabi IR. Autocrine motility factor/ phosphoglucose isomerase regulates ER stress and cell death through control of ER calcium release. Cell Death Differ. 2011; 18(6): 10571070.

28. Kho DH, Nangia-Makker P, Balan V, Hogan V, Tait L, Wang Y, Raz A. Autocrine motility factor promotes HER2 cleavage and signaling in breast cancer cells. Cancer Res. 2013; 73(4): 1411-1419.
29. Yadav RK, Chae SW, Kim HR, Chae HJ. Endoplasmic reticulum stress and cancer. J Cancer Prev. 2014; 19(2): 75-88.

30. Bravo R, Parra V, Gatica D, Rodriguez AE, Torrealba N, Paredes F, Wang ZV, Zorzano A, Hill JA, Jaimovich E, Quest AF, Lavandero S. Endoplasmic reticulum and the unfolded protein response: dynamics and metabolic integration. Int Rev Cell Mol Biol. 2013; 301: 215-290.

31. Moore K, Hollien J. Ire1-mediated decay in mammalian cells relies on mRNA sequence, structure, and translational status. Mol Biol Cell. 2015; 26(16): 2873-2884.

32. Chevet E, Hetz C, Samali A. Endoplasmic reticulum stress-activated cell reprogramming in oncogenesis. Cancer Discov. 2015; 5(6): 586597.

33. Dejeans N, Barroso K, Fernandez-Zapico ME, Samali A, Chevet E. Novel roles of the unfolded protein response in the control of tumor development and aggressiveness. Semin Cancer Biol. 2015; 33: 67-73.

34. Manié SN, Lebeau J, Chevet E. Cellular mechanisms of endoplasmic reticulum stress signaling in health and disease. 3. Orchestrating the unfolded protein response in oncogenesis: an update. Am J Physiol Cell Physiol. 2014; 307(10): C901-C907.

35. Clarke HJ, Chambers JE, Liniker E, Marciniak SJ. Endoplasmic reticulum stress in malignancy. Cancer Cell. 2014; 25(5): 563-573.

36. Hetz C, Chevet E, Harding HP. Targeting the unfolded protein response in disease. Nat Rev Drug Discov. 2013; 12(9): 703-719.

37. Bochkov VN, Philippova M, Oskolkova O, Kadl A, Furnkranz A, Karabeg E, Breuss J, Minchenko OH, Mechtcheriakova D, Hohensinner P, Rychli K, Wojta J, Resink T, Binder BR, Leitinger N. Oxidized phospholipids stimulate angiogenesis via induction of VEGF, IL-8, COX-2 and ADAMTS-1 metalloprotease, implicating a novel role for lipid oxidation in progression and destabilization of atherosclerotic lesions. Circ Res. 2006; 99(8): 900-908.

38. Lenihan CR, Taylor CT. The impact of hypoxia on cell death pathways. Biochem Soc Trans. 2013; 41(2): 657-663.

39. Denko NC. Hypoxia, HIF1 and glucose metabolism in the solid tumour. Nat Rev Cancer. 2008; 8(9): 705-713.

40. Minchenko OH, Kharkova AP, Bakalets TV, Kryvdiuk IV. Endoplasmic reticulum stress, 
its sensor and signaling systems and the role in the regulation of gene expressions in malignant tumor growth and hypoxia. Ukr Biokhim Zhurn. 2013; 85(5): 5-16. (In Ukrainian).

41. Minchenko OH.,Tsymbal DO, Minchenko DO, Riabovol OO, Halkin OV, Ratushna OO. IRE$1 \alpha$ regulates expression of ubiquitin specific peptidases during hypoxic response in U87 glioma cells. Endoplasm Reticul Stress Dis. 2016; 3(1): 50-62.

42. Minchenko OH, Tsymbal DO, Minchenko DO, Riabovol OO, Ratushna OO, Karbovskyi LL. Hypoxic regulation of the expression of cell proliferation related genes in U87 glioma cells upon inhibition of IRE1 signaling enzyme. $U k r$ Biochem J. 2016; 88(1): 11-21.

43. Minchenko DO, Kharkova AP, Halkin OV, Karbovskyi LL, Minchenko OH. Effect of hypoxia on the expression of genes encoding insulin-like growth factors and some related proteins in U87 glioma cells without IRE1 function. Endocr Regul. 2016; 50(2): 43-54.

44. Minchenko DO, Riabovol OO, Tsymbal DO, Ratushna OO, Minchenko OH. Inhibition of IRE1 signaling affects the expression of genes encoded glucocorticoid receptor and some related factors and their hypoxic regulation in U87 glioma cells. Endocr Regul. 2016; 50(3): 127-136.

45. Minchenko OH, Kryvdiuk IV, Minchenko DO, Riabovol OO, Halkin OV. Inhibition of IRE1 signaling affects expression of a subset genes encoding for TNF-related factors and receptors and modifies their hypoxic regulation in U87 glioma cells. Endoplasm Reticul Stress Dis. 2016; 3(1): 1-15.

Received 28.11.2016 